\title{
THE EFFECTS OF STRUCTURAL EMPOWERMENT ON CORPORATE REPUTATION AND ORGANIZATIONAL IDENTIFICATION
}

\author{
[Efekty strukturálního empowermentu na firemní reputaci a identifikaci] \\ Hüseyin Erkul ${ }^{1}$, Pelin Kanten², Gülten Gümüştekin ${ }^{3}$ \\ ${ }^{1}$ Canakkale Onsekiz Mart University, Faculty of Political Sciences, Turkey \\ Email:hcerkul@comu.edu.tr \\ ${ }^{2}$ Canakkale Onsekiz Mart University, Faculty of Political Sciences, Turkey \\ Email:pelinkanten@comu.edu.tr \\ ${ }^{3}$ Canakkale Onsekiz Mart University, Faculty of Political Sciences, Turkey \\ Email: ggumustekin@comu.edu.tr
}

\begin{abstract}
This study aims to investigate the effects of structural empowerment on corporate reputation and the mediating role of organizational identification. Within the literature, studies suggest that some organizational factors improve employees' perception of corporate reputation levels. Therefore, structural empowerment and organizational identification are considered as predictors' of corporate reputation levels of employees in scope of the study. For the purpose of the research, the data which were collected from 178 administrative staff in Canakkale Onsekiz Mart University by the survey method were analyzed by using hierarchical regression analysis. The results of study revealed that all dimensions of structural empowerment such as participatory decision-making environment, accountable and supportive environment and facilitative environment have positive and significant effects on employees' perception of corporate reputation levels. Besides, it was also found out that organizational identification has positive and significant effect on the perception of employees' corporate reputation levels. In addition, organizational identification has a mediating role in the relationship between structural empowerment dimensions and perception levels of employees' corporate reputation.
\end{abstract}

Keywords: administrative staff, corporate reputation, organizational identification, structural empowerment.

JEL classification: M20, J20, D23

Doručeno redakci: 7.8.2018; Recenzováno: 14.8.2018; 22.8.2018; Schváleno k publikování: 19.9.2018

\section{Introduction}

Current competitive, dynamic and global working conditions require organizations to differentiate their actions, offering and services to maintain positive relationships with stakeholder groups (Shamma 2012: 151). Due to the increasing competiton and turbulence organizations need to develop unique and distinctive resources to gain sustainable competitive advantage and success. In other words, organizational efficiency and performance depend on intangible assets of organization than the physical and financial resources. Nowadays, corporate reputation is considered as the most remarkable intangible asset that provides organizational success and competitive edge (Alniacik et al. 2011: 1178). Corporate reputation generally defined as a stakeholder's overall evaluation of an organization from past to present. This evualation reflects organizations ability to provide valued outcomes to the group of stakeholders or interest group (Walsh et al. 2009: 190). However, corporate reputation is regarded as a valuable resource that it is difficult to imitate and also to be seen as an indicator of the quality of organizations actions. Besides, corporate reputation can lead 
some favourable benefits such as profitability, lowering costs, attracting and retaining qualified employees, attracting new customer and investors and encouraging customer loyalty (Ruiz et al. 2016: 781). It is possible to express that corporate reputation enables organizations to obtain variable positive consequences such as customer retention, economic growth, service and product quality, enhanced performance, higher income and employee loyalty (Gözükara and Y1ldırım 2015: 126-127).

Corporate reputation plays a crucial role on the stakeholders' decisions such as employees willingness to work for, investors choice of investment or customers choice of buying products and services. Based upon the corporate reputation importance on stakeholders' strategic decisions, it is needed to build and manage a favorable corporate reputation and should have understood its antecedents (Maden et al. 2012: 655). In the literature, researchers asserted that there are some significant organizational antecedents of corporate reputation. For example, it is seen that researchers suggested corporate reputation significantly related with organizational commitment, job satisfaction, organizational identification, organizational trust and etc. (Tuna et al. 2014: 570). Accordingly, it can be said that some organizational antecedents facilitiate organizations to maintain a positive corporate reputation from the stakeholders' perspectives. In this context, this study aims to examine some of the antecedents of corporate reputation perception of the university administrative staff. In consideration of antecedents of corporate reputation, structural empowerment and organizational identification were evaluated. However, there is no research in the existing literature yet examining the relationships among structural empowerment, organizational identification and corporate reputation on the adiminstrative staff. Therefore, this study aims to investigate the effects of structural empowerment and organizational identification on corporate reputation. On the other hand, it aims to investigate the mediating effect of organizational identification between the relationships structural empowerment and corporate reputation so it attempts to add contribution to the literature.

\section{Conceptual Framework and Hypotheses Development}

Due to the variable and uncertain conditions, there is a need of empower employees in organizations to make quick decisions and respond rapidly to any changes in working area. Empowerment of employees has received a great attention in management field, because it is considered as crucial elements of managerial and organizational effectiveness for increasing shared power and control. However, employees' empowerment regarded as significant management technique which can be generally accepted across all public and private organizations (Hamed 2010: 65). In other words, employee empowerment has been examined as a popular idea which has penetrated in the variety of disciplines such as management, sociology, social work, nursing, psychology and political science. Main meaning of this concept in all different disciplines is to facilitate gaining organizational effectiveness by the maximum usefulness of human resources. While maximum utilization of human resources, organizations need empowered employees who take the initiative and respond creatively to the challenges of the job (Orgambídez-Ramos and Borrego-Alés 2014: 28). In the literature, it is suggested that empowerment examined from two different points of view as "the relational perspective" or "structural empowerment" and "psychological empowerment" which were introduced by Kanter (1977). While psychological empowerment considered as a bottom-up approach to empowerment, structural empowerment represents the top-down approach (MostefaIder and Al-Sulaiti 2015: 2). It is suggested that the concept of structural empowerment derives from the Theory of Power Kanter (1985). According to this theory, there are two main sources of structural empowerment which are labeled as formal 
and informal power components of organizations. Formal power components considered as job dicretion, gratitude and job relevance in contrast informal power resources are regarded like relationships between employees and organizations (Jaffery and Farooq 2015: 275).

Structural empowerment generally refers to the organization's ability to offer their employees to access to the information and resources, represents supporting conditions and opportunities in the working area. Information regarded as the knowledge of the organization which includes policies, decisions and objectives. While resources seen as necessary equipments and time to do the work, support is considered as formal and informal feedbacks from supervisor. However, opportunity reveals the access of employees to develop themselves in the organization (Q'Brien 2010: 6). Therefore, it is possible to express that access to resources and information, support, feedback and opportunity facilitates employees to accomplish their roles and tasks effectively. In addition, when the organizations maintain structural empowerment conditions, employees feel themselves empowered (Gilbert et al. 2010: 340). Structural empowerment involves organizational policies, practices and structures that give employees degree of latitude to make decisions and exert influence and also shows the power sharing between employer and employee (Bish et al. 2014: 31). In other words, structural empowerment aim employees' participation in the organizational decision-making process and leads them to have more authority and control over their task roles (Puskulluoglu and Altinkurt 2017: 120). Actually, structural empowerment allows employees to receive necessary information while performing their work roles, facilitiate they have to access sufficient resources and thus they will have opportunities to develop knowledge and skills which are expected to affect their job performance (Puncreobutr and Watttanasan 2016: 158).

In the literature, it is seen that various studies have asserted significant relationships between structural empowerment and positive attitudes and behaviors. For example, previous researches emphasized that structural empowerment leads employees to experience higher intrinsic motivation and lead them to engage in discretionary behaviours. On the other hand, it is suggested that structural empowerment cause employees emotional exhaustion and job tension levels decreasing (Gilbert et al. 2010: 340). According to the studies of Laschinger et al. (2004); Kuo et al. (2008); Lautizi et al. (2009) there is a significant relationship between structural empowerment and job satisfaction. Besides, Cho et al. (2006); Yang et al. (2014); Puncreobutr and Watttanasan (2016) emphasized that structural empowerment process lead to employees' organizational commitment levels' increasing. Therefore, it can be infferred that structural empowerment has a positive relationships between favourable organizational outcomes such as job satisfaction, organizational trust, organizational commitment, performance, positive attitudes and etc (Horwitz and Horwitz 2017, 14). However, Men (2010) and Alfalah (2017) assumed that due to the empowered employees have freedom, opportunity and authority, they may have positive feelings towards to their organizations. Because, it is thought that empowered employees have more opportunities to develop creativity, flexibility and partipating decision making process related their work roles so they will have more positive feelings and have a good reputation directed to the organizations. Accordingly, the following hypotheses are proposed:

$\mathrm{H}_{1}$ : Participatory decision-making environment influences employees' perception of corporate reputation levels.

$\mathrm{H}_{2}$ : Accountable and supportive environment influences employees' perception of corporate reputation levels.

$\mathrm{H}_{3}$ : Facilitative environment influences employees' perception of corporate reputation levels. 
Empirical research supports that employee empowerment facilitiate to create cooperation, sacrifice, loyalty and identification in the organizations. Actually, if employees perceive high level of empowerment, it is expected that they have possess high level of organizational commitment and organizational identification (Puncreobutr and Watttanasan 2016: 158). Organizational identification is considered as an integrated and crucial force which maintains positive relationship between employee and employer (Asadullah et al. 2017: 125). It refers to a spesific form of social identification that shows employee's pride of membership and reflects the sense of belongingness to the organization. According to the social identification theory, if employees strongly match their values and goals with the organization, they will exhibit positive behaviors and attitudes such as work engagement, success and extra-role behaviors (Wang and Zheng 2018: 315). However, it is seen in previous studies that organizational identification leads some positive organizational outcomes like greater job satisfaction and job performance, improved well-being and organizational commitment, lower turnover and absenteeism (Chughtai 2016: 868). Therefore, it is possible to express that organizational identification regarded as a critical construct which have a great importance on favorable organizational outcomes (Todorović et al. 2017: 872). Due to the organizational identification has been accepted a vital component for the sustainable organizational life, it is needed to reveal out the antecedents of this concept. For example previous researches Ertürk (2010); Prati and Zani (2013) found that feelings of empowerment can enhance employees' identification levels with their organization. In other words, when organizations provide development opportunities and positive working conditions, ensure accessibility to the resources and information, it is expected that employees to reciprocate by being identificated to their organization. Thus, it can be inferred that if organizations provide effective empowerment system to the employees, they will perceive that their organizations value them and it facilitiate their identification with the organization. In this context, the following hypotheses are developed:

$\mathrm{H}_{4}$ : Participatory decision-making environment influences employees' perception of organizational identification levels.

$\mathrm{H}_{5}$ : Accountable and supportive environment influences employees' perception of organizational identification levels.

$\mathrm{H}_{6}$ : Facilitative environment influences employees' perception of organizational identification levels.

In the literature, it is asserted that organizational identification can emerge depending on some organizational factors such as job characteristics, job involvement, organizational image, organizational communication, organizational trust, organizational justice, perceived organizational support and corporate reputation (Tuna et al. 2014: 571). Corporate reputation refers to the set of perceptions of an organization which are shaped during time and reveals successful activities of the organization during that time. It is considered as a set of judgement that is based on employees and stakeholders individuals' evuluation of the organization from the social, economical and environmental perspectives (Dolatabadi et al. 2012: 220). Due to its characteristics, researchers suggested that corporate reputation have to be examined as a multidimensional construct. From this point of view, it is seen that corporate reputation evaluated by under the six dimensions which has been widely accepted in the literature. These dimensions labelled as emotional appeal, products and services, financial performance, vision and leadership, work environment, and social responsibility (Karami et al. 2013: 714). Emotional appeal refers to the stakeholders positive feelings related with the organization. Products and services shows whether the organization have a high quality, innovative, reliable and value for money outputs or not. 
Financial performance regarded how stakeholders satisfied with the organization's profitability. Vision and leadership refers to the stakeholders'thoughts that the organization has a clear vision, effective leadership process, and the capability to recognize opportunities. Work environment emphasizes that the whether stakeholders believe the organization managed well, has a good relationships between employees and is a favourable place to work. Social responsibility indicates the sensitiveness of the organization to the environment and community (Men 2010: 6-7). Therefore, it can be inferred that corporate reputation plays a significant role in the eyes of stakeholder and shows requirement of the expectation of multiple stakeholders. For the reason that its importance and considered as the crucial intangible asset, organizations have to manage corporate reputation components attentively and comprehend the determinitive factors that lead to providing corporate reputation activities (Maden et al. 2012: 655-656). One of the previous researches which are belonging to Freund (2006) found out organizational commitment, job performance and organizational citizenship behaviors are significant predictors of corporate reputation. In addition Dolatabadi et al. (2012) suggested that organizational commitment and job satisfaction lead to perception of corporate reputation levels increasing. Besides, Bueno et al. (2015) asserted that organizational identification can be examined as an antecedent of corporate reputation. In this context, the following hypotheses are assumed:

$\mathrm{H}_{7}$ : Organizational identification influences employees' perception of corporate reputation levels.

Accordingly, it is expected that organizational identification will have a mediating effects on the relationship between the structural empowerment dimension and corporate reputation; as a result the following hypotheses are proposed:

$\mathrm{H}_{8}$ : Organizational identification has a mediating role on the relationship between participatory decision-making environment and corporate reputation.

$\mathrm{H}_{9}$ : Organizational identification has a mediating role on the relationship accountable and supportive environment and corporate reputation.

$\mathrm{H}_{10}$ : Organizational identification has a mediating role on the relationship between facilitative environment and corporate reputation.

Figure 1: Research Model

\section{Direct Effects}

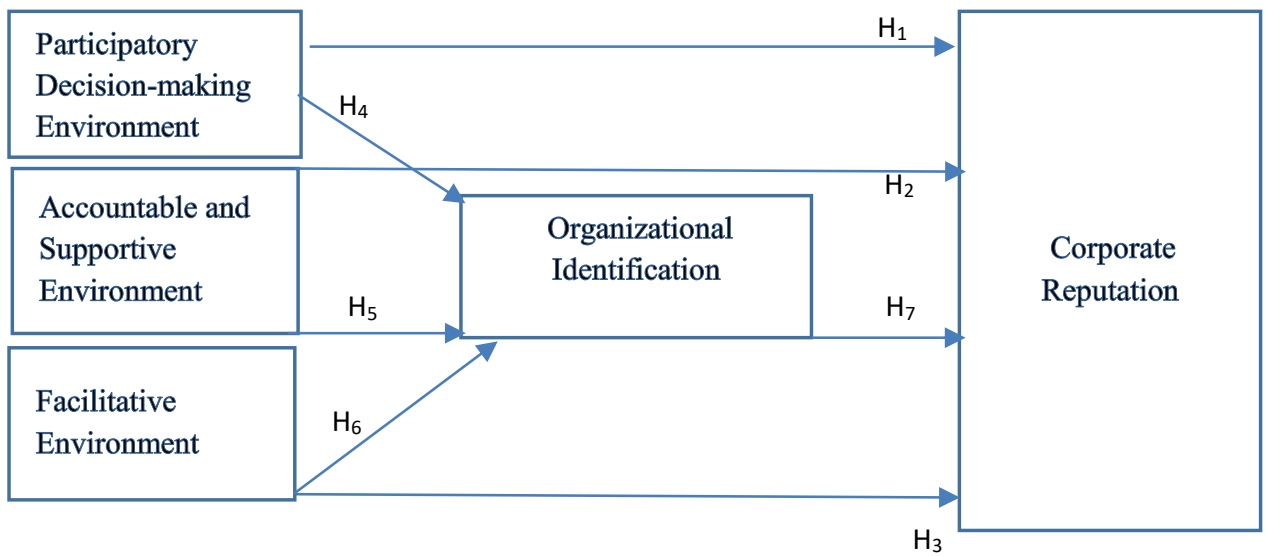

Source: Developed by Erkul et al. (2018) 
Figure 2: Research Model

Mediating Effects

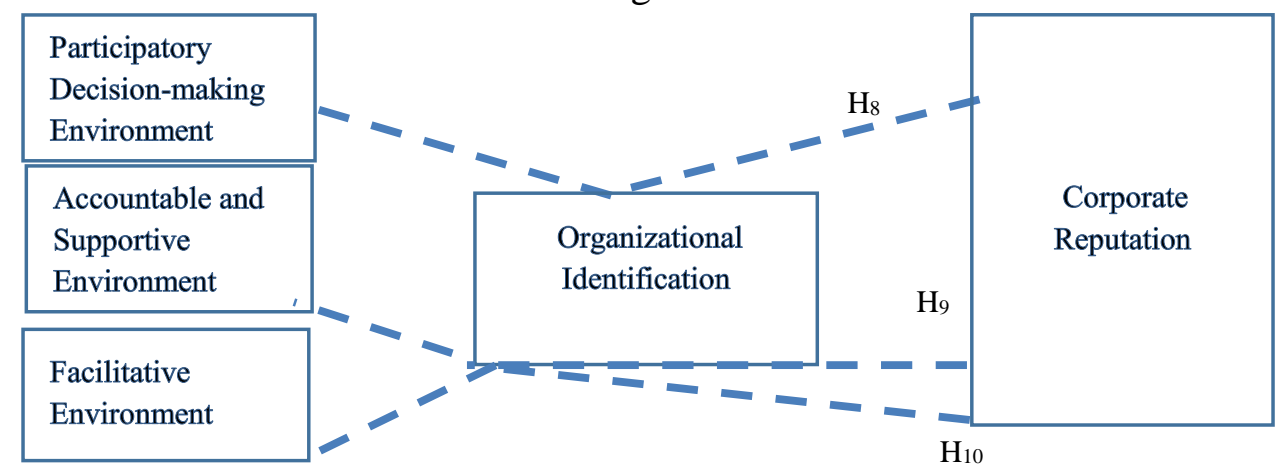

Source: Developed by Erkul et al. (2018)

\section{Research Methodology}

\subsection{Sample and Procedures}

The sample of the present research was composed of Canakkale Onsekiz Mart University's administrative staff. The participants of this study consist of 178 employees who have been working in Canakkale Onsekiz Mart University's different units determined via convenient sampling method. Out of 260 questionnaires that have been sent out, 185 have been returned, representing a response rate of $71 \%$. After the elimination of the cases that have incomplete data and outliers, 178 questionnaires $(68 \%)$ have been accepted as valid and were included in the evaluations. However, questionnaire survey method was used for data collection in this study. The questionnaire form contains three different measures related to research variables.

\subsection{Measures}

The measures used in the questionnaire forms have been adapted from the previous studies in the literature. All measures have been adapted to Turkish by the lecturers and a pilot study has been conducted for the validity of these measures. Before the distribution of the survey to the actual sample, a pilot study was conducted in order to determine whether the questions would be understood properly and to check the reliability of the scales. As a result of the pilot study, some corrections were made in the questionnaire forms. A Likert-type metric, that is, expressions with five intervals has been used for answers to the statements of survey. Anchored such; "1- strongly disagree, 2- disagree, 3- agree or not agree, 4- agree, 5-strongly agree". Moreover, 6 demographic questions were included in the questionnaire form. On the other hand, 4 open-ended questions were asked participants such as "write your suggestions about the participation of the decision making process in this institution"; "write your thoughts what should have done about the professional development of yourself in this institution"; "write your suggestions about what should have been done for provising the identification of the employees in this institution"; write your write your suggestions about what should have done for improving the working environment". All of the research scales were subjected to the exploratory factor analyses to check the dimensions, and then confirmatory factor analyses were applied to all scales. 
- Structural Empowerment Scale: Employees perception of structural empowerment levels were measured with 21 items from Puskulluoglu and Altinkurt's (2017) study. Exploratory factor analyses using principle component analysis with varimax rotation was applied to the adapted scale to check the dimensions. As a result of the varimax rotation of the data related to the structural empowerment variables, 9 items were removed from the analysis due to the factor loading under 0.50. Additionally, three factor solutions; (participatory decision-making environment, accountable and supportive environment, facilitative environment) were obtained in accordance with the theoretical structure. Some examples of the items asked to the employees are as follows: "In this institution, I have an opportunity to participate decision making process"; "In this institution, there is a formal feedback process related with the job"; "In this institution, employees have an autonomy related with the method and techniques in job process".

- Organizational Identification Scale: Employees organizational identification levels were measured with 6 items which was developed by Mael and Ashforth (1992). As a result of the exploratory factor conducted on the data related to the organizational identification variables, one factor solution was obtained in line with the theoretical structure. Some examples of the items asked to the employees are as follows: "When I talk about this institution, I usually say 'we' rather than "they"; "This instititution's successes are my successes".

- Corporate Reputation Scale: Employees perception of corporate reputation levels were measured with 20 items from Baran et al., studies (2009). Exploratory factor analyses using principle component analysis with varimax rotation was applied to the adapted scale to check the dimensions. As a result of the varimax rotation of the data related to the corporate reputation variables, 11 items were removed from the analysis due to the factor loading under 0.50 . Additionally, three factor solutions; (product and services, emotional attractiveness, working environment and vision) were obtained in accordance with the theoretical structure. Some examples of the items asked to the employees are as follows: "there is a good communication among this institution's employees"; "I esteem this institution"; "there is a good image of this institution".

Table 1: Summary Table of Exploratory Factor and Reliability Analyses

\begin{tabular}{|c|c|c|c|c|c|}
\hline $\begin{array}{l}\text { Structural } \\
\text { Empowerment } \\
\text { (remaining } 12 \text { items) } \\
\text { Variance: } 74 \%\end{array}$ & $\begin{array}{l}\text { Cron. } \\
\text { Alpha }\end{array}$ & $\begin{array}{l}\text { Corporate Reputation } \\
\text { (remaining } 9 \text { items) } \\
\text { Variance: } 87 \%\end{array}$ & $\begin{array}{l}\text { Cron. } \\
\text { Alpha }\end{array}$ & $\begin{array}{l}\text { Organizational } \\
\text { Identification } \\
\text { (remaining } 6 \text { items) } \\
\text { Variance: } 79 \%\end{array}$ & $\begin{array}{l}\text { Cron. } \\
\text { Alpha }\end{array}$ \\
\hline $\begin{array}{l}\text { 1. Factor: } \\
\text { Participatory } \\
\text { Decision-making } \\
\text { environment } \\
\end{array}$ & .852 & $\begin{array}{l}\text { 1. Factor: Emotional } \\
\text { attractiveness }\end{array}$ & .937 & $\begin{array}{l}\text { 1. Factor: } \\
\text { Organizational } \\
\text { Identification }\end{array}$ & .946 \\
\hline $\begin{array}{l}\text { 2.Factor: } \\
\text { Accountable and } \\
\text { supportive } \\
\text { environment }\end{array}$ & .895 & $\begin{array}{l}\text { 2.Factor: Product } \\
\text { and services }\end{array}$ & .925 & & \\
\hline $\begin{array}{l}\text { 3. Facilitative } \\
\text { environment }\end{array}$ & .823 & $\begin{array}{l}\text { 3.Factor: Working } \\
\text { environment } \begin{array}{l}\text { and } \\
\text { vision }\end{array}\end{array}$ & .907 & & \\
\hline
\end{tabular}

Source: Developed by Erkul et al. (2018) 
After the exploratory factor analyses, the confirmatory factor analysis has been conducted by Lisrel 8.8 for all scales. Goodness of fit indexes is presented in Table 2. It can be seen that all of the fit indexes fall within the acceptable ranges (Schermelleh-Engel et al., 2003: 52; Meydan and Şeşen, 2011: 35).

Table 2: Goodness of Fit Indexes of the Scales

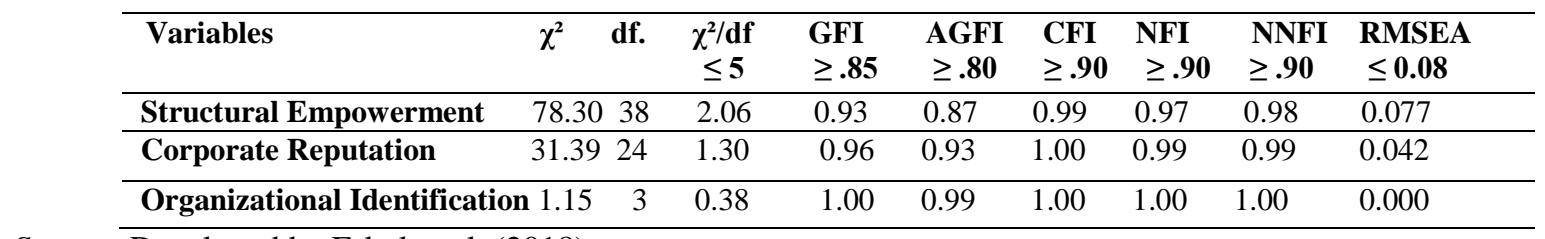

Source: Developed by Erkul et al. (2018)

\subsection{Data analysis}

SPSS for Windows 20.0 and Lisrel 8.80 programs were used to analyze the obtained data. After the exploratory and confirmatory analysis, descriptive statistics such as means, standard deviations and pearson correlation analysis of the study variables were examined. Following that, hierarchical multiple regression analysis was used to test all research hypotheses.

\section{Research findings}

\subsection{Respondent profile}

$51 \%$ of the employees' were male and $49 \%$ were female. Majority $(72 \%)$ of the employees were between the ages 30-49, $19 \%$ between the ages 20 and 29 and $9 \%$ of them older than 50 . In terms of education level, $45 \%$ had a bachelor's degree, $20 \%$ had a high school education, $\% 19$ of them had a vocational school degree, and \% 16 of the employees had master's degree. Analysis of the titles of administrative staff showed that, 52\% of the employees are working as an officer in different units, $18 \%$ of them working as a technical staff, $14 \%$ of them working as a secretary and $10 \%$ of them working as a servant, $6 \%$ of the employees are working as a security staff. However, it is seen that $32 \%$ of the participants had been working for between 1-5 years, $25 \%$ of them had been working for between 6-10 years, and 30\% of them had been working for between 11-20 years. On the other hand $13 \%$ of them had been working for more than 21 years in the same instituion.

\subsection{Descriptive analyses}

In the scope of the descriptive analyses means, standard deviations and correlations have been conducted which are related to structural empowerment, corporate reputation and organizational identification. The values are given in Table 3.

Table 3: Means, standard deviations and correlations of the study variables

\begin{tabular}{lccccccc}
\hline & Mean. & S.S & 1 & 2 & 3 & 4 & 5 \\
\hline Participatory decision-making env. & 3.22 & .97 & 1 & & & & \\
Accountable and supportive env. & 3.18 & .98 & $.824^{* *}$ & 1 & & & \\
Facilitative environment & 3.70 & .92 & $.600^{* *}$ & $.703^{* *}$ & 1 & & \\
Organizational identification & 3.65 & .96 & $.618^{* *}$ & $.726^{* *}$ & $.657^{* *}$ & 1 & \\
Corporate Reputation & 3.68 & .93 & $.651^{* *}$ & $.743^{* *}$ & $.712^{* *}$ & $.857^{* *}$ & 1 \\
\hline
\end{tabular}

${ }^{* *} p<0.01$

Source: Developed by Erkul et al. (2018) 
As can be seen in Table 3, the results of correlation analysis shows that the dimensions of structural empowerment which are labeled as participatory decision-making environment $(\mathrm{r}=.651, \mathrm{p}<0.01)$; accountable and supportive environment $(\mathrm{r}=.743, \mathrm{p}<0.01)$ and facilitative environment $(\mathrm{r}=.712$, $\mathrm{p}<0.01$ ) positively related to the perception of corporate reputation levels of employees. According to these results, it is possible to express that accountable and supportive environment conditions much more related perception of corporate reputation levels of employees. Structural empowerment dimensions as participatory decision-making environment $(\mathrm{r}=.618, \mathrm{p}<0.01)$; accountable and supportive environment $(\mathrm{r}=.726, \mathrm{p}<0.01)$ and facilitative environment $(\mathrm{r}=.657$, $\mathrm{p}<0.01)$ are positively related to the organizational identification levels of employees. On the other hand, organizational identification levels of employess $(r=.857, p<0.01)$ are positively related to corporate reputation. In this context, it can be expected that employees' organizational identification levels may have lead to their corporate reputation levels increasing.

\subsection{Hierarchical Regression Analysis}

Hierarchical multiple regression analysis was used to test all the research hypotheses and the mediating effects. The approach by Baron and Kenny (1986) was used to test mediating effects.

Table 4: Mediating Role of Organizational Identification

\begin{tabular}{|c|c|c|c|c|c|c|}
\hline Model & $\begin{array}{c}\text { Independent } \\
\text { Variables }\end{array}$ & $\begin{array}{c}\text { Dependent } \\
\text { Variable }\end{array}$ & $\mathbf{R}^{2}$ & $\beta$ & $\mathbf{F}$ & $\mathbf{p}$ \\
\hline \multirow[t]{3}{*}{1} & $\begin{array}{c}\text { Participatory } \\
\text { decision-making env. }\end{array}$ & \multirow{3}{*}{$\begin{array}{l}\text { Corporate } \\
\text { Reputation }\end{array}$} & .424 & $.651 * *$ & 129.669 & .000 \\
\hline & $\begin{array}{l}\text { Accountable and } \\
\text { supportive env. }\end{array}$ & & .552 & $.743 * *$ & 216.989 & .000 \\
\hline & $\begin{array}{c}\text { Facilitative } \\
\text { environment }\end{array}$ & & .507 & $.712 * *$ & 181.168 & .000 \\
\hline \multirow[t]{4}{*}{$\begin{array}{l} \\
\text { Model Included } \\
\text { Mediating } \\
\text { Variable }\end{array}$} & $\begin{array}{c}\text { Participatory } \\
\text { decision-making env. } \\
\text { Sobel test: } z=9.451 \\
\mathrm{p}=0.000\end{array}$ & \multirow{4}{*}{$\begin{array}{l}\text { Corporate } \\
\text { Reputation }\end{array}$} & .758 & $.197 * *$ & 274.328 & .000 \\
\hline & $\begin{array}{c}\text { Accountable and } \\
\text { supportive env. } \\
\text { Sobel test: } \mathrm{z}=11.874 \\
\mathrm{p}=0.000\end{array}$ & & .765 & $.256 * *$ & 284.946 & .000 \\
\hline & $\begin{array}{c}\text { Facilitative } \\
\text { environment } \\
\text { Sobel test: } z=10.223 \\
p=0.000\end{array}$ & & .773 & $.263 * *$ & 298.722 & .000 \\
\hline & $\begin{array}{c}\text { Organizational } \\
\text { Identification }\end{array}$ & & .734 & .857 & 485.984 & .000 \\
\hline
\end{tabular}

Source: Developed by Erkul et al. (2018)

According to the results, participatory decision-making environment $(\beta=.651, p<0.001)$; accountable and supportive environment $(\beta=.743, p<0.001)$ and facilitative environment $(\beta=.712$, $\mathrm{p}<0.001$ ) have positive and significant effect on employees perception of corporate reputation levels, thus $\mathrm{H}_{1}, \mathrm{H}_{2}, \mathrm{H}_{3}$ hypotheses were supported. Organizational identification level has positive and significant effect $(\beta=.857, \mathrm{p}<0.001)$ on employees perception of corporate reputation levels so $\mathrm{H}_{7}$ hypothesis was supported. In addition to this, participatory decision-making environment $(\beta=.618, p<0.001)$; accountable and supportive environment $(\beta=.726, p<0.001)$ and facilitative environment $(\beta=.657, \mathrm{p}<0.001)$ have positive and significant effect on employees organizational 
identification levels, therefore $\mathrm{H}_{4}, \mathrm{H}_{5}$, and $\mathrm{H}_{6}$ hypotheses were supported. Moreover, considering the mediator role of organizational identification, it has been observed that the effects of participatory decision-making environment $(\beta=.197, \mathrm{p}<0.001)$, accountable and supportive environment $(\beta=.256, p<0.001)$ and facilitative environment $(\beta=.263, p<0.001)$ on corporate reputation have been continued but decreased. In this regard, it can be claimed that the conditions of Baron and Kenny approaches were provided and organizational identification has a partially mediator role on the relationship between all dimensions of structural empowerment and corporate reputation. As a result, $\mathrm{H}_{8}, \mathrm{H}_{9}$ and $\mathrm{H}_{10}$ hypotheses were supported.

\section{Findings and Discussion}

In the contemporary business world, corporate reputation is considered as one of the inimitable and valuble intangible assets of the organizations which has a crucial impact on stakeholders' attitudes and behaviors. Due to the volatile and global working conditions, organizations need to have some spesific strategies that facilitiate them to obtain success and competitive edge. One of these strategies called as corporate reputation which enables organization to a make a favourable image and impression in the eyes of stakeholders. In other words, corporate reputation demonstrates the organizations' ability to fulfill the interest and objectives of stakeholders which composed of employees, suppliers, customers, investors and government. However, it plays an essential role on the choices of stakeholders such as attracting and retaining qualified employees, investing new areas or not and desires to buy products or services. Accordingly, it is possible to express that corporate reputation bring about positive outcomes from the organizational perspective such as meeting customer demands, increasing employee and financial performance and enhancing customer satisfaction. Based on the importance, organizations need to maintain their activities considering the corporate reputation and also they have to identify the antecedents of this concept as for understanding how could be achieved a positive image. In this context, this study aims to examine some antecedents of the corporate reputation which are addressed as structural empowerment and organizational identification.

As a result of the research findings, it has been found that all dimensions of structural empowerment such as participatory decision-making environment, accountable and supportive environment and facilitative environment have significant effect on perception of corporate reputation levels of employees, so hypotheses $\mathrm{H}_{1}, \mathrm{H}_{2}$ and $\mathrm{H}_{3}$ were supported. These results reveal that when organizations provide favourable and supportive conditions for their employees, it is expected them to have a positive image related with their institutions. In case of the organization provide sufficient resources and information, adequate support, feedback and opportunity to the employees for performing their work roles efficiently; it is thought that maintaining and sustaining good image is easier. Due to the structural empowerment providing employees to take part in decision-making process and strengthen them as giving authorization and responsibility, it is assumed that employees may have a feelings of pride and reputation towards to their organizations. In addition, it has been obtained that all dimensions of structural empowerment as participatory decisionmaking environment, accountable and supportive environment and facilitative environment have significant effect on perception of organizational identification levels of employees, so hypotheses $\mathrm{H}_{4}, \mathrm{H}_{5}$ and $\mathrm{H}_{6}$ were supported. Therefore, it can be inferred that if organizations provide structural empowerment conditions, employees may perceive that their organizations give value to them and they may have positive feelings such as belonginess and identification. Consequently, it is possible to express that carrying out structural empowerment process efficiently may increase perception of corporate reputation and organizational identification levels of employees who work as an 
administrative staff in the university. In other words, it is possible express that university staff are regarded as qualified people, so it is crucial to empower them in their work process. Because, it is believed that when employees impowered, they are more prone to show loyalty and commitment towards to their organizations.

As it can be seen from the results, organizational identification has a significant effect on employees' perception of corporate reputation levels, so hypotheses $\mathrm{H}_{7}$ was supported. Hence, when employees have a positive attititudes towards to their employers and colleagues and also have a psychological attachment, they will evualuate their organizations more respected and honourable places. However, it is supposed that employees who identify themselves with their organizations, they may perceive their institution as a emotional attractiveness place which has a good quality product and services, and a good vision and leadership. In addition, employees may have committed to their organizations incase it has a favourable financial performance, supportive workplace environment and functional social responsibility activities. On the other hand, considering the mediator roles of organizational identification, it was found that organizational identification had a partially mediator role on the relationship between structural empowerment dimensions and corporate reputation so $\mathrm{H}_{8}, \mathrm{H}_{9}, \mathrm{H}_{10}$ hypotheses were supported. Therefore, it can be inferred that employees may have positive feelings to their organization in the case of having a perception that they have been empowered and have the feeling of identification. In other words, when organizations provide some favourable conditions to their employees such as authorization, partipation to the decision-making process, accessibility to resources and information, it is expected that their perception of corporate reputation levels increase if they possess a idenitication simultaneously. Consequently, it is seen that there are some studies concerning the antecedents of corporate reputation in different industries but it is scarce in public institutions. In this context, this study aims to examine some organizational antecedents by exploring the relationships among research variables. According to this research, it can be said that public institiutions need to empower their employees to obtain a positive image in the eyes of stakeholders and to ensure them to identificated with their institutions. When public institutions provide their employees favourable conditions, it is expected that they tend to have more positive feelings and positive image. For future studies, it is recommended that the research model can be tested on larger samples and industries such as manufacturing and service. Moreover, the research model can be redesigned by adding some other variables which are taught to be antecedents of corporate reputation levels such as organizational trust, organizational injustice and corporate social responsibilities. Besides, it can be questioned whether some factors like organizational-based self-esteem, work engagement and organizational commitment are mediating variables or not.

\section{References}

[1] ALNIACIK, U., E. CIGERIM, E. AKCIN and O. BAYRAM, 2011. Independent and Joint Effects of Perceived Corporate Reputation, Affective Commitment and Job Satisfaction on Turnover Intentions. Procedia Social and Behavioral Sciences, 24, p. 1177-1189.

[2] ALFALAH, T. F., 2017. The role of leadership styles in building and sustaining corporate reputation - empirical investigation on Islamic banks in Jordan, International Review of Management and Marketing, Vol. 7(3), p. 227-232. 
[3] ASADULlAH, M. A., A. AKRAM, H. IMRAN and G. A. ARAIN, 2017. When and which employees feel obliged: A personality perspective of how organizational identification develops. Journal of Work and Organizational Psychology, Vol. 33, p. 125-135.

[4] BARAN, M., S. KANTEN and M. BOZKURT, 2009. Reputation Management and Customer Loyalty: An Emprical Study. 7Th International Logistics \& Supply Chain Congress, 5th -6th November, İstanbul.

[5] BARON, R. M. and D. A. KENNY, 1986. The Moderator-Mediator Variable Distinction in Social Psychological Research: Conceptual, Strategic, and Statistical Considerations, Journal of Personality and Social Psychology, Vol. 51 (6), p. 1173-1182.

[6] BISH, M., A. KENNY and R. NAY, 2014. Perceptions of structural empowerment: nurse leaders in rural health services. Journal of Nursing Management, Vol. 22, p 29-37.

[7] BUENO, E., M. LONGO-SOMOZA, R. GARCÍA-REVILLA and R. DIANA LEON, 2015. Management Challenges in the identification of Organizational Identity and Corporate Reputation as Intangible Assets. Electronic Journal of Knowledge Management, Vol. 13(3), p. $173-185$.

[8] CHO J., H. K. LASCHINGER and C. WONG, 2006. Workplace empowerment, work engagement and organizational commitment of new graduate nurses. Canadian Journal of Nursing Leadership, Vol. 19(3), p. 43-60.

[9] CHUGHTAI, A. A., 2016. Servant leadership and follower outcomes: mediating effects of organizational identification and psychological safety. The Journal of Psychology, Vol. 150, No. 7, p. 866-880.

[10] DOLATABADI, H. R., T. GHUJALI and M. SHAHMOHAMMADI, 2012. Analysis of Employees' Awareness from Their Manner of Impact on the Organizational Reputation. International Journal of Business and Social Science, 3(3), p. 220-229.

[11] ERTÜRK, A., 2010. Exploring predictors of organizational identification: Moderating role of trust on the associations between empowerment, organizational support, and identification. European Journal of Work and Organizational Psychology, Vol. 19 (4), p. 409-441.

[12] FREUND, A., 2006. Work and Workplace Attitudes on Social Workers: Do They Predict Organizational Reputation?. Business and Society Review, 111(1), p. 67-87.

[13] GILBERT, S., H. K. S. LASCHINGER and M. LEITER, 2010. The mediating effect of burnout on the relationship between structural empowerment and organizational citizenship behaviours. Journal of Nursing Management, Vol. 18, p. 339-348.

[14] GÖZÜKARA, İ. and O. YILDIRIM, 2015. Affective Commitment and Corporate Reputation. The Effects of Attitude toward Advertising and Trust. Academic Journal of Economic Studies, Vol. 1(3), p. 126-147.

[15] HAMED, S. S., 2010. Antecedents and consequences of employees' empowerment. Management Review: An International Journal, Vol. 5, No. 1, p. 64-94.

[16] HORWITZ, S. K. and I. B. HORWITZ, 2017. The effects of organizational commitment and structural empowerment on patient safety culture: An analysis of a physician cohort. Journal of Health Organization and Management, Vol. 31(1), p.10-27. 
[17] JAFFERY, H. and H. FAROOQ, 2015. The impact of structural empowerment on organizational citizenship behavior-organization and job performance: a mediating role of. Journal of Management Sciences, Vol. 2(2), p. 273-288.

[18] KANTER, R. M., 1977. Men and women of the corporation. New York, NY: Basic Books; http://www.apa.org/pubs/journals/features/apl-96-5-981.pdf.

[19] KARAMI, S., H. SOLTANPANAH and M. RAHMANI, 2013. The Relationship between Corporate Reputation and Organizational Citizenship Behavior in Private Banks City of Sanandaj in Iran. Interdisciplinary Journal of Contemporary Research in Business, 5(3), p. 713-725.

[20] KUO, H. T., T. J. C. YIN and I. C. LI, 2008. Relationship between organizational empowerment and job satisfaction perceived by nursing assistants at long-term care facilities. Journal of Clinical Nursing, Vol. 17, p. 3059-3066.

[21] LASCHINGER, H. K. S., J. E. FINEGAN, J. SHAMIAN and P. WILK, 2004. A longitudinal analysis of the impact of workplace empowerment on work satisfaction, Journal of Organizational Behavior, Vol. 25, p. 527-545.

[22] LAUTIZI, M., H. K. S. LASCHINGER and S. RAVAZZOLO, 2009. Workplace empowerment, job satisfaction and job stress among Italian mental health nurses: an exploratory study. Journal of Nursing Management, Vol. 17, p. 446-452.

[23] MADEN, C., E. ARIKAN, E. TELCI and D. KANTUR, 2012. Linking corporate social responsibility to corporate reputation: a study on understanding behavioral consequences. Procedia - Social and Behavioral Sciences, Vol. 58, 655-664.

[24] MAEL, F. and B. E. ASHFORTH, 1992. Alumni and their alma mater: A partial test of the reformulated model of organizational Identification. Journal Of Organizational Behavior, Vol. 13, p. 103-123.

[25] MEN, L. R., 2010. Measuring the Impact of Leadership Style and Employee Empowerment on Perceived Organizational Reputation. Doctoral Thesis, University of Miami, Miami.

[26] MEYDAN, C. H. and H. ŞEŞEN, 2011. Yapısal Eşitlik Modellemesi AMOS Uygulamaları. Ankara: Detay Yayıncilık.

[27] MOSTEFAIDER, AL-SULAITI, A. S., 2015. Antecedents of structural empowerment and the relationship between structural empowerment and performance. Proceedings of 9th AsiaPacific Business Research Conference 5-6 November, Bayview Hotel, Singapore, p. 1-23, ISBN: 978-1-922069-87-0.

[28] O'BRIEN, J. L., 2010. Structural empowerment, psychological empowerment and burnout in registered staff nurses working in outpatient dialysis. For the degree of Doctor of Philosoph, The State University of New Jersey, New Jersey.

[29] ORGAMBÍDEZ-RAMOS, A. and Y. BORREGO-ALÉS, 2014. Empowering employees: structural empowerment as antecedent of job satisfaction in university settings. Psychological Thought, Vol. 7(1), p. 28-36.

[30] PRATI, G. and B. ZANI, 2013. The relationship between psychological empowerment and organizational identification. Journal of Community Psychology, Vol. 41, No. 7, p. 851-866. 
[31] PUNCREOBUTR, V. and P. WATTTANASAN, 2016. Structural empowerment and organizational commitment of lecturers in private international educational institutions at Thailand, Journal of Education and Practice, Vol.7, No. 11, p. 158-163.

[32] PUSKULLUOGLU, E. I. and Y. ALTINKURT, 2017. Development of teachers' structural empowerment scale (TSES): a validity and reliability study. Üniversitepark Bülten, Vol. 6(1), p. 118-132.

[33] RUIZ, B., J. A. GARCÍA and A. J. REVILLA, 2016. Antecedents and consequences of bank reputation: a comparison of the United Kingdom and Spain. International Marketing Review, Vol. 33(6), p.781-805.

[34] SCHERMELLEH-ENGEL, K., H. MOOSBRUGGER and H. MÜLLER, 2003. Evaluating the Fit of Structural Equation Models: Tests of Significance and Descriptive Goodness-of-Fit Measures. Methods of Psychological Research, Vol. 8 (2), p. 23-74.

[35] SHAMMA, H. M., 2012. Toward a comprehensive understanding of corporate reputation: concept, measurement and implications. International Journal of Business and Management; Vol. 7, No. 16, p. 151-169.

[36] TODORAVIC, D., M. CABARKAPA, M. TOSIC-RADEV and I. MILADINOVIC, 2017. Organizational identification, commitment and orientations of professional military personnel, Vojnosanit Pregl, Vol. 74(9), p. 871-877.

[37] TUNA, M., M. YEŞILTAŞ and P. KANTEN, 2014. The Effects of Corporate Reputation on Affective Commitment: Mediating Role of Organizational Factors. Global Interdisciplinary Business-Economics Advancement Conference, Florida, ABD, 15-18 May 2014, p.569-580.

[38] YANG, J., Y. LIU, Y.CHEN and X. PAN, 2014. The effect of structural empowerment and organizational commitment on Chinese nurses' job satisfaction. Applied Nursing Research Vol. 27, p. 186-191.

[39] WALSH, G., V. W. MITCHELL, P. R. JACKSON and S. E. BEATTY, 2009. Examining the Antecedents and Consequences of Corporate Reputation: A Customer Perspective. British Journal of Management, 20, p. 187-203.

[40] WANG, Y., Y. ZHENG and Y. ZHU, 2018. How transformational leadership influences employee voice behavior: the roles of psychological capital and organizational identification. Social Behavior and Personality, Vol. 46(2), p. 313-322. 